DOI: $10.26693 / j m b s 05.06 .218$

UDC 616.699-008:546.48:614.7

Onul N. M., Biletska E. M., Holovkova T. A.

\title{
EFFECT OF CADMIUM EXPOSURE ON MALE FERTILITY
}

\author{
State Institution “Dnipropetrovsk Medical Academy of Health Ministry of Ukraine”, \\ Dnipro, Ukraine
}

sangreena_@ukr.net

Among the xenobiotics of diverse nature, heavy metals are especially dangerous for the human reproductive system in case of excessive intake. Cadmium, which is one of the most common toxic substances for the environment and production, can pose a potential threat to human health. An increasing amount of cadmium in the environmental objects and in nutrition is believed to be related to a poor semen quality.

The purpose of the study was to determine the impact of cadmium on the reproductive potential of men who live in ecologically contrasting conditions.

Material and methods. Clinical and hygienic assessment of the reproductive health was carried out among 2 experimental groups: the $1^{\text {st }}$ group consisted of fertile men living in the city of Dnipro (62 respondents), the $2^{\text {nd }}$ group included men with normal fertility living in the control city (37 respondents). To determine the cadmium concentration, venous blood samples and ejaculate were selected according to the standard methods. Biological samples were transferred to aliquots, frozen and stored at $-20^{\circ} \mathrm{C}$ until analysis. The research was carried out using inversion voltammetry on the device AVA-2. Statistical processing of the results was carried out using statistical software packages of statistical analysis Statistica v.6.1 (Statsoftlnc., СШA, licence NAJAR909E415822FA), Microsoft Excel.

Results and discussion. Cadmium content in the blood and in the sperm of the fertile men of industrial city 1.3-5.8 times higher than the results of research in the control city and literature data. Differences between the cadmium content in the blood and semen of fertile men was shown to be unlikely, suggesting that the hematotesticular barrier is insufficient to protect the male reproductive organs from the toxic effects of the metal. The ejaculate in the fertile men of the studied cities is characterized by normosospermia and meets the standards. However in the residents of the industrial city the ejaculate quality indices were mostly at the lower level of the norm and were significantly worse than in the residents of the control city. Cadmium contained in male biosubstrates affect the hormonal status and quality of semen.

Conclusion. Violations of spermatogenesis can serve as a rapidly-responding and reliable criterion for assessing the adaptation and maladaptation processes of men under the influence of xenobiotics of the environment, in particular cadmium. In this case, the markers of influence are the total number of sperm in the ejaculate, their concentration, mobility and the number of pathological forms, semen viscosity.

Keywords: cadmium, exposure, biomonitoring, fertility, ejaculate.

Research relation to the programs, plans, and department themes. The study was carried in accordance with the department research work: "Hygienic diagnostics of forming of ecologically dependent microelementosis among the population of industrial region and their prophylaxis», the State registration number is 0114 U005582.

Introduction. The problem of preserving and strengthening of the reproductive health of the population is becoming one of the key medical and social issues $[1,2]$. At the same time infertility rate continues to trend higher in this century and about $15 \%$ of couples in different populations are infertile and male causes of infertility account for $40-50 \%$ [3]. The causes of male infertility are complex and the etiology of about $50 \%$ of male infertility remains unknown. Although genetic factors can explain a few percentages of male infertility, increasing environmental pollution might also contribute to the persistent increase of male infertility [4].

The male appears more susceptible than the female to the effects of occupational or environmental exposures to reproductive toxicants, and it is not surprising that environmental agents have been postulated to be contributory to deteriorating semen quality and a decline in male reproductive health [5]. Studies of the effects of environmental agents on semen quality in man have largely focused on organic toxicants with potential endocrine disrupting activity, but heavy and transition metal endocrine disruptors, may be influential as well [6].

Among the xenobiotics of diverse nature, heavy metals are especially dangerous for the human reproductive system in case of excessive intake [7].

Cadmium, which is one of the most common toxic substances for the environment and production, can pose a potential threat to human health [8]. The general population is exposed to cadmium mainly via drinking water and food products. It accumulates and is proved to cause severe damage to a variety of organs [9]. Due to its high toxicity and cumulative effect, 
cadmium easily leads to multi-organ injury, especially to the genital system $[10,11]$.

An increasing amount of cadmium in the environmental objects and in nutrition is believed to be related to a poor semen quality. The reproductive effects of cadmium are complex and numerous studies in animal models (mainly rodents) and growing evidence from human epidemiological research point to the adverse effects of cadmium on male fertility [3, 12].

Therefore, we conducted an ongoing study to assess two questions: whether cadmium levels in blood and seminal plasma differ among men living in ecologically contrasting conditions; and whether cadmium levels in blood and seminal plasma affect normal sperm parameters and hormone levels.

The purpose of research was to determine the impact of cadmium on the reproductive potential of men who live in ecologically contrasting conditions.

Material and methods. Clinical and hygienic assessment of reproductive health was carried out in Dnipropetrovs'k region [5]. All patients gave informed consent to the use of research results for a scientific purpose without the indication of personal data. They underwent a series of studies in accordance with the standard protocol [13] to form 2 groups: the $1^{\text {st }}$ group included fertile men living in the city of Dnipro (62 respondents), the $2^{\text {nd }}$ group consisted of men with normal fertility living in the control city (37 respondents). The age of the subjects was within the range of 20-50 years. All researches are approved by the Commission on Biomedical Ethics of the SI DMA.

To determine the cadmium concentration, venous blood samples and ejaculate were selected according to the standard methods $[13,14]$. Biological samples were transferred to aliquots, frozen and stored at $-20^{\circ} \mathrm{C}$ until analysis. The research was carried out using inversion voltammetry on the device AVA-2. In addition, to study the peculiarities of metals translocation from the blood to the male reproductive organs, the index of penetration through the hemato-testicular barrier (IPB) - the ratio of metal concentration in the ejaculate to its content in the whole blood, conventional units (c.u.) was calculated.

As it is well-known [1, 6], the hormonal status, quantitative and qualitative characteristics of the sperm are the criteria for the full value of the male fertility status. To assess gonadotoxic effects of the environmental ecological factors and quality of sperm, ejaculate of males with varying fertility was selected in accordance with WHO requirements [13, 14, 15].

Statistical processing of the results was carried out using statistical software packages of statistical analysis Statistica v.6.1 (Statsoftlnc., USA, licence NAJAR909E415822FA), Microsoft Excel.

Results. As a result of the conducted research, it was found that the concentrations of cadmium (table 1) in the blood of residents of the region range from 0.0011 to $0.0355 \mathrm{mg} / \mathrm{l}$, which is an average of $0.0097 \pm 0.0008 \mathrm{mg} / \mathrm{l}$ with higher rates among the male population of the industrial city although without a significant difference.

The content of cadmium in the ejaculate of fertile men at average values was $0.008 \pm 0.001 \mathrm{mg} / \mathrm{l}$, 1.3 times higher among the male population of the industrial city $(p<0.05)$. Differences in the content of cadmium in the blood and sperm of fertile men were unreliable.

Therewith, calculated index - the index of penetration of xenobiotic cadmium through the hemato-testicular barrier is quite high and is $0.82 \mathrm{c.u}$., that is, the predominant amount of this metal from the blood penetrates into the testicles (table 1).

Table 1 - The cadmium concentration in biosubstrates of fertile men, mg/l

\begin{tabular}{|c|c|c|c|}
\hline \multirow{2}{*}{$\begin{array}{c}\text { City of } \\
\text { study }\end{array}$} & \multirow{2}{*}{$\mathrm{N}$} & \multicolumn{2}{|c|}{ Biosubstrates of fertile men } \\
\cline { 3 - 4 } & & venous blood & ejaculate \\
\hline industrial & 62 & $0.0107 \pm 0,0011^{\circ 0}$ & $0.009 \pm 0.001^{*}$, ,oo \\
\hline control & 37 & $0.0081 \pm 0.0013^{\circ}$ & $0.0067 \pm 0,0004^{\circ}$ \\
\hline total & 99 & $0.0097 \pm 0.0008^{\circ \circ}$ & $0.008 \pm 0.001^{\circ \circ}$ \\
\hline
\end{tabular}

Notes: * $-p<0,05$ in comparison with the control city; ${ }^{\circ}-p<0,05 ;{ }^{\circ}-p<0,01 ;{ }^{\circ 00}-p<0,001$ in comparison with the literature data

Complex clinical and hygienic studies have established that gonadotropic activity and the level of testosterone in the blood plasma of fertile men are characterized by minor variable rate changes in the indexes of secretory activity and are within the limits of physiological fluctuations $-4.9-23.0 \mathrm{nmol} / \mathrm{l}$ for testosterone, $2.3-10.3 \mathrm{mU} / \mathrm{ml}$ - for follicle stimulating hormone, $5.4-8.6 \mathrm{mU} / \mathrm{ml}$ - for luteinizing hormone. The content of testosterone in the blood plasma of industrial city men was by $4.2 \%$ lower $(p<0.01)$ compared with similar results in the control city, while the activity of follicle stimulating hormone and luteinizing hormone secretion, by contrast, was increased by $8.9-15.5 \%(p<0.05)$.

The results of the study of the fertility potential of men in the Dnipropetrovsk region indicate (table 2) that the semen volume varied within 2-6 ml. The viscosity of semen varied within $0-0.5 \mathrm{~cm}$ and, on average was $0.34 \pm 0.02$ and $0.23 \pm 0.02 \mathrm{~cm}$ in the industrial and control cities respectively. The time of the ejaculate liquefaction in fertile men was within 20-40 minutes, the $\mathrm{pH}$ reaction was weakly alkaline and within 7,4-7,8 c.u.

The total amount and concentration of sperm in the ejaculate of the fertile men was $90.14 \pm 5.58$ on average and $96.09 \pm 6.83,25.61 \pm 1.01$ and $28.53 \pm 1.11$ $\mathrm{million} / \mathrm{ml}$ in industrial and control cities respectively. 
Table 2 - Indicators of fertility potential of men in the industrial region

\begin{tabular}{|c|c|c|c|c|c|}
\hline \multirow{3}{*}{ Index } & \multicolumn{4}{|c|}{ City of study } & \multirow{3}{*}{$\begin{array}{c}\text { Norm, } \\
\text { WHO } \\
{[6]}\end{array}$} \\
\hline & \multicolumn{2}{|c|}{ industrial } & \multicolumn{2}{|c|}{ control } & \\
\hline & $\mathrm{M} \pm \mathrm{m}$ & $\min -\max$ & $M \pm m$ & min-max & \\
\hline semen volume, $\mathrm{ml}$ & $3.38 \pm 0.12$ & $2.0-6.0$ & $3.42 \pm 0.13$ & $2.0-5.0$ & $\geq 1.5$ \\
\hline $\mathrm{pH}$ & $7.79 \pm 0.006^{000}$ & $7.6-7.8$ & $7.71 \pm 0.017$ & $7.4-7.8$ & $\geq 7.2$ \\
\hline semen viscosity, $\mathrm{cm}$ & $0.34 \pm 0.02^{000}, \cdots$ & $0-0.5$ & $0.23 \pm 0.02 \cdots$ & $0-0.5$ & $<0.5$ \\
\hline time of the ejaculate liquefaction, $\min$ & $34.11 \pm 0.58 \cdots$ & $20-40$ & $33.13 \pm 0.85 \cdots$ & $20-40$ & $<60$ \\
\hline total amount of sperm, mln & $90.14 \pm 5.58^{\circ}, \cdots$ & $32-300$ & $96.09 \pm 6.83 \cdots$ & $40-200$ & $\geq 39$ \\
\hline sperm concentration, $\mathrm{mln} / \mathrm{ml}$ & $25.61 \pm 1.01 \cdots$ & $15-50$ & $28.53 \pm 1.10^{\cdots}$ & $15-41$ & $\geq 15$ \\
\hline generally-moving spermatozoa $(\mathrm{A}+\mathrm{B}), \%$ & $63.39 \pm 0.61 \cdots$ & $51-72$ & $62.63 \pm 0.68 \cdots$ & $53-69$ & $\geq 32$ \\
\hline progressively-moving spermatozoa $(A+B+C), \%$ & $82.13 \pm 0.44 \cdots$ & $75-90$ & $81.19 \pm 0.64 \cdots$ & $72-87$ & $\geq 40$ \\
\hline number of live forms of sperm, $\%$ & $72.15 \pm 1.19^{\cdots, * \circ}$ & $59-92$ & $75.28 \pm 1.03$ & $64-88$ & $\geq 58$ \\
\hline number of forms with normal morphology, \% & $57.96 \pm 1.40$ & $32-80$ & $59.19 \pm 1.11$ & $48-74$ & $\geq 4$ \\
\hline number of pathologi-cally modified forms, $\%$ & $42.04 \pm 1.40$ & $20-68$ & $40.8 \pm 1.11$ & $26-52$ & - \\
\hline
\end{tabular}

Notes: ${ }^{*}-p<0.05 ;{ }^{* *}-p<0.01 ;{ }^{* *}-p<0.001$ in comparison with the recommended norm; ${ }^{\circ}-p<0.05 ;{ }^{\circ}-p<0.01$; ${ }^{\circ 00}-p<0.001$ in comparison with the control city; $-p<0.05 ; \cdot-p<0.01 ; \cdots-p<0.001$ in comparison with the infertile group

The progressive sperm motility was $63.39 \pm 0.61$ and $62.63 \pm 0.68 \%$ in industrial and control cities respectively. A similar situation was observed with respect to the generally-moving spermatozoa. The number of live forms of sperm in the fertile men of both cities under observation ranged from $51-92 \%$ and averaged 72.15-75.28\%.

The number of forms with normal morphology in all experimental groups ranged from $14-80 \%$. Pathologically modified forms of spermatozoa occur with the frequency from $40.8 \pm 1.1 \%$ in fertile men in the control city, to $42.04 \pm 1.40 \%$ in the industrial city (table 2).

Using correlation and regression analysis were found an increase in the content of cadmium in the blood and in the ejaculate causes a probable decrease in testosterone levels $(r=-0.96 ; p<0.05)$ with simultaneous activation of gonadotropin secretion ( $r=0.94-0.97 ; p<0.01)$. Cadmium, contained

Table 3 - Parameters of regression models of the influence of cadmium concentration in the blood on the reproductive potential of men in the industrial region

\begin{tabular}{|l|c|c|c|c|c|}
\hline \multirow{2}{*}{ Index } & \multicolumn{4}{|c|}{ Parameters of regression models } \\
\cline { 2 - 6 } & $\mathbf{a}$ & $\mathbf{m}_{\mathbf{a}}$ & $\mathbf{b}$ & $\mathbf{m}_{\mathbf{b}}$ & $\mathbf{x}^{*}$ \\
\hline Testosterone, nmol/l & 22.07 & 0.16 & -301.66 & 11.69 & 0.001 \\
\hline Luteinizing hormone, $\mathrm{mO} / \mathrm{ml}$ & 6.59 & 0.17 & 38.01 & 14.19 & 0.004 \\
\hline $\begin{array}{l}\text { Follicle stimulating hormone, } \\
\mathrm{mO} / \mathrm{ml}\end{array}$ & 2.63 & 0.55 & 535.12 & 40.35 & 0.001 \\
\hline $\begin{array}{l}\text { Number of pathologically } \\
\text { modified forms, \% }\end{array}$ & 36.27 & 0.31 & 598.38 & 22.68 & 0.001 \\
\hline $\begin{array}{l}\text { Generally-moving } \\
\text { spermatozoa (A+B), \% }\end{array}$ & 64.76 & 1.15 & -226.44 & 96.67 & 0.005 \\
\hline
\end{tabular}

Notes: $\mathrm{a}$ and $\mathrm{b}$ - model parameters; ma and $\mathrm{mb}$ - model parameter errors; $x$ * - critical levels of influence of the factor in male biosubstrates affects the quality of semen - it leads to the increase of the sperm viscosity and the number of pathological forms of spermatozoa $(r=0.93-0.98 ; p<0.01)$, the decrease in the total number of spermatozoa, their concentration and mobility $(r=-0.90--0.98 ; p<0.01)$.

Reliable single-factor regression models of the effect of the influence of cadmium concentration in the blood on the reproductive potential of men in the industrial region $\left(p<0.05-p<0.001, R^{2}=0.87-0.98\right)$ are presented in table 3.

Discussion. The results showed that the cadmium content in the blood and in the sperm of the fertile men even at average values 1.3-5.8 times higher than the results of research in the control city and literature data $(p<0.05-p<0.01)$ on the content of this abiotic metal in the blood and ejaculate of almost healthy men who do not have occupational hazards and do not smoke $[6,7,16,17]$. Differences between the cadmium content in the blood and semen were shown to be unlikely, suggesting that the hematotesticular barrier is insufficient to protect the male reproductive organs from the toxic effects of the metal.

The revealed differences in the toxicant levels in the biosubstrates of the fertile men coincide with the results of other studies [3, 4, 9] and testify to an active accumulation of cadmium in the ejaculate, which probably leads to the violation of the fertile properties of the sperm and, along with other factors, may be a risk factor for infertility development. The latter assumption is confirmed by the high 
value of IPB, which indicates that the overwhelming majority of cadmium penetrates from the blood to the testicles which are particularly susceptible to cadmium [10]. The reason for this may be that, according to the data $[2,9,18]$ cadmium reproductive toxicity is mediated by multiple mechanisms, including direct damage to testis vasculature and blood-testis barrier, inflammation, cytotoxicity on Sertoli and Leydig cells, oxidative stress mainly by means of mimicry and interference with essential ions, apoptosis, interference with selected signaling pathways and epigenetic regulation of genes involved in the regulation of reproductive function, and disturbance of the hypothalamus-pituitary-gonadal axis, raising the level of entropy in the morphofunctional system of the testicles due to the combined action of intravascular (slow blood flow, change in blood rheology), intrmural (damage to the epithelium and serous cells, damage to the integrity of the basement membrane) and extravascular factors (perivascular fibrosis).

Comparison of the ejaculate quality results in the men of the control and industrial city reveiled, that in the control city the semen volume complied with the norm in all cases, while in the industrial city this finding was lower than the regulatory level - $39 \mathrm{mln}$ in $7.7 \%$ of the patients surveyed. It should be noted that in the residents of the industrial city the ejaculate quality indices were mostly at the lower level of the norm and were significantly worse than in the residents of the control town, especially concerning viscosity, sperm concentration and number of the live forms $-6.0-32.4 \%$ $(p<0.01)$, which coincides with similar studies $[1,8]$.

Having grouped all the detected changes in spermograms, we found that the ejaculate in the fertile men of the studied cities is characterized by normosospermia and meets the standards [18]. It should be noted that today there are ongoing discussions among scholars [15] regarding the adequacy of the existing reference values of spermograms in accordance with the latest WHO recommendations, since they are significantly understated and do not fully characterize the fertilizing properties of the ejaculate.

Data of the complex clinical and hygienic research of the reproductive health of men of Dnipropetrovsk region are largely supplemented by the results of correlation and regression analysis. It was found that cadmium contained in male biosubstrates affect the hormonal status which is consistent with the data of other authors, according to which [2] cadmium mimics the function of steroid hormones; therefore, this "metallohormone" has been proposed as endocrine disruptor interfering with endogenous endocrine system. It has been shown that cadmium can directly bind to estrogen receptor and androgen receptor and exerts strong estrogenic-like and androgenic-like actions, both in vivo and in vitro.

Cadmium, contained in male biosubstrates affects the quality of semen - it leads to the increase of the sperm viscosity and the number of pathological forms of spermatozoa, the decrease in the total number of spermatozoa, their concentration and mobility. This ties up with the data of other authors regarding the negative influence on spermatogenesis with deterioration of ejaculate quality in men with concentration of cadmium [17, 20].

\section{Conclusion}

1. Cadmium content in the blood and in the sperm of the fertile men 1.3-5.8 times higher than the results of research in the control city and literature data $(p<0.05-p<0.01)$. Differences between the cadmium content in the blood and semen of fertile men have been shown to be unlikely, suggesting that the hematotesticular barrier is insufficient to protect the male reproductive organs from the toxic effects of the metal.

2. The ejaculate in the fertile men of the studied cities is characterized by normosospermia and meets the standards. However, in the residents of the industrial city the ejaculate quality indices were mostly at the lower level of the norm and were significantly worse than in the residents of the control city.

3. Cadmium contained in male biosubstrates affect the hormonal status and quality of semen. We propose single-factor regression models of the effect of the influence of cadmium concentration in the blood on the reproductive potential of men in the industrial region, that can be used for diagnosing and predicting fertility potential of men according to the data of cadmium biomonitoring.

Prospective for the further research. We propose single-factor regression models of the effect of the influence of cadmium concentration in the blood on the reproductive potential of men in the industrial region that can be used for diagnosing and predicting fertility potential of men according to the data of cadmium biomonitoring.

\section{References}

1. Merzenich H, Zeeb H, Blettner M. Decreasing sperm quality: a global problem? BMC Public Health. 2010; 10: 24.

2. De Angelis C, Galdiero M, Pivonello C, Salzano C, Gianfrilli D, Piscitelli P, et al. The environment and male reproduction: the effect of cadmium exposure on reproductive system and semen quality and its implication in fertility. Reprod Toxicol. 2017; 73: 105-127. doi: 10.1016/j.reprotox.2017.07.021

3. Zhu Q, Li X, Ge RS. Toxicological effects of cadmium on mammalian testis. Front Genet. 2020 May 26; 11: 527. doi: 10.3389/fgene.2020.00527 
4. Gao Y, Mruk DD, Cheng CY. Sertoli cells are the target of environmental toxicants in the testis - a mechanistic and therapeutic insight. Expert Opin Ther Targets. 2015; 19(8): 1073-1090. doi: 10.1517/14728222.2015.1039513

5. Onul NM, Biletska EM, Stus VP, Polion MYu. The role of lead in the etiopathogenesis of male fertility reduction. Wiadomości Lekarskie. 2018; LXXI(6): 1155-1160.

6. Benoff S, Hauser R, Marmar JL, Hurley IR, Napolitano B, Centola GM. Cadmium concentrations in blood and seminal plasma: correlations with sperm number and motility in three male populations (infertility patients, artificial insemination donors, and unselected volunteers). Mol Med. 2009; 15(7-8): 248-262. doi: 10.2119/ molmed.2008.00104

7. Alaee S, Talaiekhozani A, Rezaei S, Alaee K, Yousefian E. Cadmium and male infertility. Journal of Infertility and Reproductive Biology. 2014; 2(2): 62-69.

8. Zhou Z, Lu YH, Pi HF, Gao P, Li M, Zhang L, et al. Cadmium exposure is associated with the prevalence of dyslipidemia. Cell Physiol Biochem. 2016; 40(3-4): 633-643. doi: 10.1159/000452576

9. Pavlova E, Atanassova N. Impact of cadmium on male fertility. Acta morphologica et anthropologica. 2018; 25(1-2): 108-116.

10. Alkhedaide A, Alshehri ZS, Sabry A, Abdel-Ghaffar T, Soliman MM, Attia H. Protective effect of grape seed extract against cadmium-induced testicular dysfunction. Mol Med Rep. 2016; 13(4): 3101-3109. doi: 10.3892/ mmr.2016.4928

11. Niknafs B, Salehnia M, Kamkar M. Induction and determination of apoptotic and necrotic cell death by cadmium chloride in testis tissue of mouse. J Reprod Infertil. 2015; 16(1): 24-29.

12. Wang HF, Chang M, Peng TT, Yang Y, Li N, Luo T, et al. Exposure to cadmium impairs sperm functions by reducing catsper in mice. Cell Physiol Biochem. 2017; 42(1): 44-54. doi: 10.1159/000477113

13. WHO Laboratory Manual for the Examination and Processing of Human Semen. $5^{\text {th }}$ edition. Geneva: WHO Press; 2010. 287 p.

14. Dolhov VV, Luhovskaia SA, Fanchenko ND. Laboratory diagnosis of male infertility. Tver: OOO «Yzd-vo «Tryada»; 2006. 145 p.

15. Cooper TG, Noonan E, von Eckardstein S, Auger J, Baker HW, Behre HM, et al. World Health Organization reference values for human semen characteristics. Human Reprod Update. 2010 May-Jun; 16(3): 231-45. doi: 10.1093/humupd/dmp048

16. Mendiola J, Torres-Cantero AM, Moreno-Grau JM, Ten J, Roca M, Moreno-Grau S, et al. Exposure to environmental toxins in males seeking infertility treatment: a case-controlled study. Reprod Biomed. 2008; 16(6): 842850. doi: 10.1016/s1472-6483(10)60151-4

17. Famurewa AC, Ugwuja El. Association of blood and seminal plasma cadmium and lead levels with semen quality in non-occupationally exposed infertile men in Abakaliki, South East Nigeria. J Family Reprod Health. 2017 Jun; 11(2): 97-103.

18. Romaniuk AM, Moskalenko YuV, Sauliak SV, Bonchev SD, Moskalenko RA. Vascular parenchymal ratios of the testicles when correction of the influence of compounds of heavy metals. Likarska sprava. 2013; 4: 122-127.

\section{Удк 616.699-008:546.48:614.7}

\section{НАСЛІДКИ ВПЛИВУ КАДМІЮ НА ФЕРТИЛЬНІСТЬ ЧОЛОВІКІВ}

Онул Н. М., Білецька Є. М., Головкова Т. А.

Резюме. Серед ксенобіотиків різноманітної природи важкі метали особливо небезпечні для репродуктивної системи людини у разі надмірного споживання. Кадмій, який є одним із найпоширеніших токсичних речовин для навколишнього середовища та виробництва може становити потенційну загрозу репродуктивному здоров'ю чоловіків.

Mema - визначити вплив кадмію на репродуктивний потенціал чоловіків, які проживають в екологічно контрастних умовах.

Клініко-гігієнічна оцінка репродуктивного здоров'я була проведена серед фертильних чоловіків, які проживають у місті Дніпро (62 респонденти) та у контрольному місті (37 респондентів).

Вміст кадмію в крові та спермі фертильних чоловіків, які мешкають у промисловому місті у 1,35,8 рази перевищує результати досліджень у контрольному місті та дані літератури. Відмінності між вмістом кадмію в крові та спермі фертильних чоловіків $€$ недостовірними, що свідчить про те, що гематотестикулярний бар'єр не в достатній мірі захищає чоловічі репродуктивні органи від токсичного впливу металу. Еякулят у фертильних чоловіків досліджуваних міст характеризується нормососпермією і відповідає існуючому нормативу. Однак у жителів промислового міста показники якості еякуляту були переважно на нижній межі норми і гіршими, ніж у жителів контрольного міста. Кадмій, що міститься в чоловічих біосубстратах, впливає на гормональний статус та якість сперми. 
Порушення сперматогенезу можуть служити швидко реагуючим та надійним критерієм для оцінки процесів адаптації та дезадаптації чоловіків під впливом ксенобіотиків довкілля, зокрема кадмію. У цьому випадку маркерами впливу є загальна кількість сперматозоїдів в еякуляті, їх концентрація, рухливість і кількість патологічних форм, в'язкість сперми.

Ключові слова: кадмій, вплив, біомоніторинг, фрертильність, еякулят.

\section{Удк 616.699-008:546.48:614.7}

\section{ПОСЛЕДСТВИЯ ВЛИЯНИЯ КАДМИЯ НА ФЕРТИЛЬНОСТЬ МУЖЧИН}

Онул Н. М., Белецкая Э. Н., Головкова Т. А.

Резюме. Среди ксенобиотиков различной природы тяжелые металлы особенно опасны для репродуктивной системы в случае чрезмерного потребления. Кадмий, который является одним из самых распространенных токсичных веществ для окружающей среды и производства может представлять потенциальную угрозу репродуктивному здоровью мужчин.

Цель - определить влияние кадмия на репродуктивный потенциал мужчин, проживающих в экологически контрастных условиях.

Клинико-гигиеническая оценка репродуктивного здоровья была проведена среди фертильных мужчин, проживающих в городе Днепр (62 респондента) и в контрольном городе (37 респондентов).

Содержание кадмия в крови и сперме фертильных мужчин, проживающих в промышленном городе в 1,3-5,8 раза превышает результаты исследований в контрольном городе и данные литературы. Различия между содержанием кадмия в крови и сперме фертильных мужчин являются недостоверными, что свидетельствует о том, что гематотестикулярный барьер не в достаточной мере защищает мужские репродуктивные органы от токсического воздействия металла. Эякулят у фертильных мужчин исследуемых городов характеризуется нормоспермией и соответствует нормативу. Однако у жителей промышленного города показатели качества эякулята были преимущественно на нижней границе нормы, и хуже, чем у жителей контрольного города. Кадмий, содержащийся в биосубстратах мужчин, влияет на гормональный статус и качество спермы.

Нарушение сперматогенеза может служить быстро реагирующим и надежным критерием для оценки процессов адаптации и дезадаптации мужчин под влиянием ксенобиотиков окружающей среды, в частности кадмия. В этом случае маркерами воздействия является общее количество сперматозоидов в эякуляте, их концентрация, подвижность и количество патологических фрорм, вязкость спермы.

Ключевые слова: кадмий, влияние, биомониторинг, фрертильность, эякулят.

The authors of this study confirm that the research and publication of the results were not associated with any conflicts regarding commercial or financial relations, relations with organizations and/or individuals who may have been related to the study, and interrelations of coauthors of the article. 